\title{
Cantando a dor do outro: o caso Zuzu Angel e a canção como testemunho na obra de Chico Buarque
}

\author{
Singing someone else's pain: Zuzu Angel's story and the song as a \\ historical testimony in Chico Buarque's work
}

\section{Cantando el dolor del otro: el caso de Zuzu Angel y la canción como testimonio en el trabajo de Chico Buarque}

\author{
Amilcar Almeida Bezerra, \\ amilcar.bezerra@gmail.com | https://orcid.org/o000-0002-5596-9615 \\ Patrícia Barcelos ${ }^{2, b}$ \\ pelb4@hotmail.com | https://orcid.org/0000-0002-2538-0308
}

\footnotetext{
${ }^{1}$ Universidade Federal de Pernambuco, Centro Acadêmico do Agreste, Núcleo de Design e Comunicação. Caruaru, PE, Brasil.

${ }^{2}$ Fundação Oswaldo Cruz, Instituto de Comunicação e Informação Científica e Tecnológica em Saúde, Programa de Pós-Graduação em Informação e Comunicação em Saúde. Rio de Janeiro, RJ, Brasil.

a Doutorado em Comunicação pela Universidade Federal Fluminense.

b Mestrado em Psicossociologia pela Universidade Federal do Rio de Janeiro.
}

\section{RESUMO}

Neste artigo, discutimos a estetização do testemunho histórico sob a forma da canção popular em duas obras do compositor Francisco Buarque de Holanda: Angélica (1981) e Pedaço de mim (1978). Ambas se inspiram no caso Zuzu Angel, uma famosa estilista de moda, amiga do compositor, que teve seu filho morto pela ditadura civil militar em 1971, e faleceu num controverso acidente de carro em 1976. Partindo das reflexões de autores como Benjamin, Agamben, Halbwachs, Seligmann-Silva e Blacking, procuramos discutir como a canção popular pode ser uma forma peculiar tanto de expressar a natureza do trauma, como de trazer à tona aspectos específicos de uma suposta verdade testemunhal.

Palavras-chave: Música Popular Brasileira; Testemunho; Trauma; Memória coletiva; Ditadura Militar 


\section{ABSTRACT}

In this article we discuss the aesthetization of historical testimony in two songs by composer Francisco Buarque de Holanda: Angélica (1981) and Pedaço de mim (1978), both inspired in the story of Zuzu Angel, a Brazilian fashion stylist whose son was killed by the government during Brazilian civil military dictatorship in 1971. Zuzu Angel died in a mysterious car accident in 1976. We cite authors such as Benjamin, Agamben, Halbwachs, Seligmann-Silva and Blacking to discuss how a popular song can be a peculiar way to express the nature of the trauma and to bring to light specific features of an alleged testimonial truth.

Keywords: Brazilian Popular Music; Historical testimony; Trauma; Collective memory; Military Dictatorship

\section{RESUMEN}

En este artículo, discutimos la estetización del testimonio histórico en forma de canción popular en dos obras del compositor Francisco Buarque de Holanda: Angélica (1981) y Pedaço de mim (1978), ambas inspiradas en el caso de Zuzu Angel, una famosa estilista brasileña cuyo hijo fue asesinado por la dictadura civil militar en 1971, y murió en un controvertido accidente automovilístico en 1976. De las reflexiones de autores como Benjamin, Agamben, Halbwachs, Seligmann-Silva y Blacking, buscamos discutir como la canción popular puede ser una forma peculiar tanto de expressar la naturaliza del trauma como de sacar a la luz aspectos específicos de la supuesta verdad de um testimonio.

Palabras clave: Música Popular Brasileña; Testimonio; Trauma; Memória colectiva, Ditadura Militar

Contribuição dos autores:

Concepção e desenho do estudo: Amilcar Almeida Bezerra e Patrícia Estrella Liporace Barcelos.

Aquisição, análise ou interpretação dos dados: Amilcar Almeida Bezerra e Patrícia Estrella Liporace Barcelos.

Redação do manuscrito: Amilcar Almeida Bezerra e Patrícia Estrella Liporace Barcelos.

Revisão crítica do conteúdo intelectual: Amilcar Almeida Bezerra e Patrícia Estrella Liporace Barcelos.

Declaração de conflito de interesses: não há.

Fontes de financiamento: não houve.

Considerações éticas: não há.

Agradecimentos/Contribuições adicionais: não há.

Histórico do artigo: submetido: 20 mar. 2020 | aceito: 22 ago. 2020 | publicado: 17 dez. 2020.

Apresentação anterior: não houve.

Licença CC BY-NC atribuição não comercial. Com essa licença é permitido acessar, baixar (download), copiar, imprimir, compartilhar, reutilizar e distribuir os artigos, desde que para uso não comercial e com a citação da fonte, conferindo os devidos créditos de autoria e menção à Reciis. Nesses casos, nenhuma permissão é necessária por parte dos autores ou dos editores. 


\section{INTRODUÇÃO}

Temos presenciado, nos últimos tempos, um tensionamento sem precedentes das narrativas oficiais sobre acontecimentos históricos outrora tidos como de incontestável veridicidade. No Brasil, um dos exemplos mais emblemáticos dessa tendência global - impulsionada por um contexto de falta de confiança nas instituições e de hipervalorização da experiência pessoal vetorizados pelas redes sociais on-line - é o recente questionamento da existência da ditadura civil militar que vigorou no país entre os anos de 1964 e 1985. Largamente documentada em inúmeras publicações históricas, em depoimentos de perseguidos políticos e sobreviventes das torturas registrados em livros, periódicos, mídias sonoras e audiovisuais, a ditadura civil militar brasileira é um acontecimento histórico cujos testemunhos podem hoje ser facilmente acessados por qualquer indivíduo que se interesse pelo tema. Porém, o próprio presidente da República chegou a declarar que nunca houve ditadura no Brasili, fala endossada por milhões de seus seguidores nas mais diversas redes sociais ${ }^{1}$. Tal situação nos levou a refletir sobre:

a) as limitações do testemunho como relato portador de uma suposta verdade histórica;

b) as possíveis estratégias de mobilização de afetos, no que diz respeito à compreensão, ao dimensionamento e à valoração do evento histórico e a sua incorporação à memória coletiva.

Neste ensaio, analisaremos as canções Angélica e Pedaço de mim, do escritor e compositor brasileiro Francisco Buarque de Holanda, também conhecido como Chico Buarque, que têm como temas a história de uma mulher e a dor de sua perda. Buscaremos discuti-las à luz dos operadores testemunho e trauma, entendendo que a história que as músicas narram é emblemática do período que constituiu a ditadura militar no Brasil, iniciado pelo golpe civil militar em 1964.

Seus personagens são reais: conhecida como Zuzu Angel, Zuleika Angel Jones (1921-1976) foi uma brasileira de classe média, estilista de moda reconhecida internacionalmente. Seu filho, Stuart Angel, militante político de esquerda, desapareceu em 1971 na cidade do Rio de Janeiro ${ }^{2,3}$. Segundo testemunhas, em depoimentos à recente investigação conduzida pela Comissão Nacional da Verdade, constam em arquivos da Aeronáutica documentos que provam que Stuart teria sido morto dois dias depois de seu desaparecimento. O paradeiro do corpo jamais foi descoberto, mas houve testemunho de que haveria sido atirado em alto-mar4.

Narrativas e documentos reunidos em reportagens, exposições, livros, filmes, acervos digitais afirmam que Zuzu procurou incessantemente o filho na época do desaparecimento e depois conduziu investigações sobre o seu paradeiro ${ }^{2,3}$. Organizou protestos, divulgou a história em cartas para intelectuais, artistas, políticos e militares, vestiu negro em eventos e gritou em tribunais. Morreu em abril de $1976 \mathrm{em}$ um acidente de carro provocando suspeitas de que tenha ocorrido em decorrência de uma sabotagem, hipótese também endossada por testemunho5.

Partindo especialmente das reflexões de Agamben $^{6}$, Benjamin 7 , Seligmann-Silva ${ }^{8}$, Halbwachs ${ }^{9}$ e Blacking ${ }^{10}$, procuramos discutir os efeitos da estetização do testemunho e de como a canção pode ser uma maneira tanto de expressar a natureza do trauma como de trazer à tona aspectos específicos de uma suposta verdade testemunhal na história.

Para esta análise, consideraremos, além da experiência relatada nas canções, aspectos formais de suas expressões poéticas e musicais, por entendermos, como Blacking ${ }^{10}$, que a singularidade da forma artística - no caso, musical - pode ser análoga à comunicação de aspectos específicos da experiência; e, como Agamben $^{6}$, que o testemunho pode atuar como fundamento do poema, no caso, da expressão estetizada.

Em 29 de março de 2019 a declaração foi feita ao jornalista José Luiz Datena, no programa Brasil Urgente da Rede Bandeirantes de televisão, sendo comentada por diversas matérias jornalísticas como a de 27 de março do jornal Folha de S.Paulo. 


\section{A QUESTÃO DO TESTEMUNHO E A POSSIBILIDADE DE (RE)CONSTRUÇÃO DA MEMÓRIA}

A noção de testemunho para efeitos jurídicos revela uma visão naturalística de verdade (como no exemplo do nome da citada Comissão Nacional da Verdade), sendo as pessoas que testemunham seus porta-vozes. Etimologicamente, como nos lembra o filósofo Agamben ${ }^{6}$, a palavra deriva de dois termos do latim: supertis, a pessoa que sobreviveu ao evento e pode narrá-lo, e testis, aquele que se coloca no lugar de terceiro, um imparcial que testemunhou o ocorrido, mas não necessariamente sofreu algum dano. Já a sentença, ou res judicata, é o fato julgado, que se põe no lugar da verdade ou da justiça sobre o ocorrido.

$\mathrm{O}$ teor de irrealidade do testemunho, diferente de outras formas consideradas mais técnicas e materiais de prova, gera desconfiança jurídica por traduzir uma singularidade não literal do evento. Nesse aspecto, muito se fala a respeito das limitações do testemunho como instância capaz de traduzir e comunicar com fidelidade experiências vividas.

Benjamin7, ao discorrer sobre o declínio da cultura oral no Ocidente, chegou a vaticinar que a incomunicabilidade da experiência subjetiva seria uma característica intrínseca à Modernidade. A chamada erfahrung - termo por ele utilizado para designar uma suposta experiência comum compartilhável - acabaria por desintegrar-se no turbilhão da Modernidade, que tensiona a estabilidade dos valores culturais tradicionais e cria condições para experiências-limite mais diferenciadas e singulares. A erlebnis - experiência vivida -, por sua vez, ocuparia progressivamente um lugar central na escala de valores desta cultura, na medida em que a existência da narrativa (entendida como materialização e transmissão de experiência comunicável e incorporável) estaria cada vez mais comprometida. Desta forma, Benjamin ${ }^{7}$ sugere que a condição do indivíduo moderno é atravessada pela dificuldade crônica de traduzir vivências individuais em experiências 'modelares' para a coletividade.

Agamben ${ }^{6}$, do mesmo modo, atribui ao 'testemunho' uma incompletude intrínseca. Segundo ele, é da natureza do próprio testemunho a incapacidade da transmissão precisa e completa do acontecido ao qual se refere. Porém, isso não se relacionaria com uma eventual dificuldade de comunicar experiências íntimas, mas sim com "uma realidade que excede seus elementos factuais"'(p. 20). A experiência-limite de Auschwitz é utilizada pelo autor como exemplo emblemático de que a descrição pretensamente fiel dos fatos não é suficiente para compreender a dimensão do acontecido. Deste modo, uma mesma história pode ser relatada de inúmeras formas, mas nem a soma de todos os relatos existentes é capaz de esgotar as infinitas narrativas possíveis sobre um evento histórico. Para o autor, o que falta ao testemunho diz respeito a uma aporia própria ao conhecimento histórico: "a não coincidência entre fatos e verdade, entre constatação e compreensão" (p. 20). A lacuna é parte essencial do testemunho. Portanto, 'sua verdade' estaria em possibilitar a compreensão de que sempre algo lhe escapa.

Tendo como referência a psicanálise freudiana e pensando a cena testemunhal em comparação com a cena psicanalítica, Seligmann-Silva ${ }^{8}$ aponta que o componente imaginário do testemunho é o que o torna possível, por preencher as lacunas da memória individual que foram suprimidas "quando se trata da percepção da memória do trauma" (p. 105). Propõe que o "trabalho de síntese de imagens" (p.107) é essencial no testemunho, sendo esta reorganização fundamental para a possibilidade de relatar a cena, como em qualquer registro literário que se pretenda "sério e representacionista" (p.107).

Com foco na vivência individual, a psicanálise considera o trauma como ferida aberta, experiência que não foi simbolizada, e que por isso se repete, sendo revivida em forma de sintoma ou nos sonhos. O trauma é uma violência efetiva na experiência do sujeito, tendo como contrapartida a suspensão da posição estratégica ocupada pelo outro na economia psíquica ${ }^{8}$. Poder falar (ou testemunhar) seria uma possibilidade do sujeito se reintegrar com o outro e refazer o laço rompido no passado traumático.

Partindo desses entendimentos, análises de obras literárias sobre o Holocausto mostram um certo distanciamento entre os sobreviventes do campo de concentração, que gozavam de privilégios devido a 
interesses em seus conhecimentos técnicos ou políticos, e aqueles que não sobreviveram para testemunhar - ou os que foram "totalmente destruídos em sua capacidade de resistir"8 (p.104). Há também relatos sobre sonhos obsessivos de sobreviventes, em que se viam narrando suas histórias, ao retornar para casa, mas que, quando tentavam narrá-las concretamente, sentiam algo como uma barreira entre eles e os outros.

Seligmann-Silva ${ }^{8}$ pontua que os que ouviam as narrativas traumáticas podiam reforçar essa barreira, por dificuldade em suportar o relato em negação ou por vínculo com o grupo que provocou a violência (buscando lhe dar continuidade simbólica e apagar as marcas dos crimes). O testemunho como "carência absoluta de narrar" (p.102) (o que em termos psicanalíticos se compreenderia como a necessidade da descarga psíquica) teria o desafio de derrubar essa barreira. Desse modo, "a memória do trauma é sempre uma busca de compromisso entre o trabalho de memória individual e outro construído pela sociedade”8 (p.103).

Dessa forma, movendo nosso foco para o sujeito ou para a coletividade, a construção ou reconstrução da memória parece envolver o compartilhamento de afetos, a escuta e o acolhimento do relato sobre a experiência vivida, mesmo que de extrema violência, como laço de verdade entre sujeitos.

\section{O TESTEMUNHO E A MEMÓRIA DA DITADURA CIVIL MILITAR BRASILEIRA}

Ao tratar das relações entre memória individual e coletiva, Halbwachs ${ }^{9}$ afirma que jamais estamos sozinhos em nossas lembranças. Segundo ele, a existência de uma comunidade afetiva é premissa necessária para a construção, manutenção e transformação tanto da memória coletiva quanto da individual. É o contato recorrente entre indivíduos de um mesmo grupo que cria as condições para que seus membros pensem de maneira parecida sobre certos temas, compartilhem memórias em comum e confundam, por vezes, sua memória individual com a memória do grupo.

Com relação ao testemunho, Halbwachs ${ }^{9}$ ressalta que a nossa capacidade de identificação se dá na medida em que nós e as testemunhas façamos parte de um mesmo grupo, ou de uma mesma comunidade afetiva. É o uso e o reconhecimento de noções comuns aos membros da comunidade afetiva que permite, num ato de empatia, nos colocarmos momentaneamente do ponto de vista da testemunha, mesmo que não tenhamos diretamente vivenciado a experiência relatada.

A relação entre memória individual e coletiva fica mais evidente considerando eventos históricos vividos com grande carga afetiva por determinados grupos, como genocídios, perseguições violentas ou ainda tragédias coletivas relacionadas aos fenômenos da natureza. Nesses casos, o testemunho pode se tornar, ao mesmo tempo, a tarefa individual da narrativa do trauma e o registro de sua componente coletiva. A vivência coletiva desses eventos torna possível nomeá-los como "catástrofes históricas" (p.103), em que memória individual e coletiva se interferem necessariamente.

A memória coletiva da ditadura civil militar brasileira é um exemplo de "catástrofe histórica" (p. 103) por ser uma soma de catástrofes pessoais, familiares, vividas com grande carga afetiva por determinados grupos em um determinado contexto histórico. Essas vivências, no entanto, são confrontadas por experiências distintas de negação ou favorecimento e vinculação ideológica com o regime.

Neste trabalho nos interessa especialmente distinguir as vivências dos que se opunham publicamente ao regime militar (políticos do antigo Movimento Democrático Brasileiro, oposições sindicais, a Igreja, os grupos de resistência armada) e as da classe média intelectualizada, composta por estudantes politicamente ativos, professores universitários, profissionais liberais, artistas, jornalistas, entre outros. O segundo grupo, embora fosse contrário ao regime como o primeiro, participava da resistência mais na dimensão de sua vida privada do que em sua dimensão pública, financiando movimentos e até abrigando pessoas em situação de necessidade ${ }^{11}$.

Como vimos, no entanto, em determinados contextos, os limites entre a dimensão privada (considerando seu registro na memória individual) e a dimensão pública (considerando seu registro na memória coletiva) 
das vivências ficam especialmente imprecisos. No regime de exceção, qualquer ação "envolvia riscos pessoais impossíveis de serem avaliados de antemão"11 (p. 328). Tragédias pessoais ocorreram mesmo com quem não se considerava um veemente opositor.

Coube, então, aos sobreviventes desses grupos reconstruir suas memórias mais ou menos traumáticas, narrando suas histórias (muitas vezes lutando por legitimá-las oficialmente) como forma de não perpetuar a violência sofrida em sua forma simbólica. Também como no Holocausto, durante a ditadura civil militar brasileira muitas foram as formas de expressão, cuja temática envolvia as violências infligidas a si e a outros.

\section{A MÚSICA COMO FORMA DE EXPRESSÃO E A CANÇÃO COMO TESTEMUNHO}

As produções artísticas, entre elas a experiência musical, são os exemplos mais clássicos de formações sublimatórias, recorrendo novamente ao referencial psicanalítico. As formações sublimatórias são formas simbólicas em que é possível organizar vivências pessoais, traumáticas ou não, em forma de cultura, como resultado do redirecionamento da energia psíquica para modos criativos de simbolização $0^{\mathrm{ii}}$ que não a narrativa direta ${ }^{12}$. Formas de expressão organizadas culturalmente podem servir de ponte entre o individual e o coletivo em diferentes contextos, como o do testemunho do trauma.

Williams ${ }^{13}$, um dos autores seminais nos estudos culturais, utilizando referenciais da teoria crítica e da teoria psicanalítica, propõe uma convergência entre os "sentidos antropológico e sociológico" (p.13), no entendimento da cultura. Para o autor, é possível conciliar o entendimento de um "modo de vida global" na cultura (sentido antropológico) e um "sistema de significações" (p.13) observado nas formas de atividade social, vinculada às suas condições históricas e às dimensões específicas de uma forma cultural (sentido sociológico $)^{13}$. Analisando a obra do autor, Gomes ${ }^{14}$ compreende que ambos os sentidos podem reconstituirse em experiências pessoais: "A cultura articula, ao mesmo tempo, elementos exteriores, da estrutura, e elementos da experiência pessoal, privada"14 (p.31).

Apoiado na dialética marxista entre infraestrutura/superestrutura, Williams ${ }^{13}$ não considera que a primeira determine a segunda, já que uma "organização econômica básica não podia ser separada e afastada de suas implicações morais e intelectuais” ${ }^{\prime 3}$ (p. 289). Avalia como negativo o sentido de reprodução, falseamento ou manipulação ideológica na produção artística e cultural, acentuando o sentido da criatividade na relação entre sistemas sociais e formas culturais e o "processo ativo de produção de sentido na cultura"14(p. 36).

Ao pensar sobre as funções desempenhadas pela música na vida social, o etnomusicólogo Blacking ${ }^{10}$ afirma que, apesar de sua especificidade e de sua textura particular, o fenômeno estético só pode ser compreendido em interação com outros modos de atividade social. A música é apenas um entre os muitos quadros de símbolos por meio dos quais "as pessoas aprendem a produzir um sentido público de seus sentimentos e da vida social” ${ }^{\prime \prime}$ (p. 205).

No artigo intitulado Música, cultura e experiência, ele se preocupa em definir a natureza específica da música como produção artística, relacionada a um tipo específico de experiência humana e a um "sistema modelar primário do pensamento humano"10 (p. 208). O autor compreende a música como uma capacidade humana, um quadro específico das capacidades cognitivas e sensoriais. Acrescentamos, como hipótese, que a música também está associada a um tipo específico de memória, particularmente afetiva, sensível, corporal, que articula registros individuais e coletivos. A música, dessa forma, caminharia por um modo específico de simbolizar, capaz de inscrever na memória individual e coletiva certas experiências analogamente específicas da ordem do sensível e dos afetos.

ii Neste artigo, aproximaremos 'estetização' e 'sublimação' como formas de conceber dimensões pragmáticas e psíquicas do processo de criação artística. 
Blacking ${ }^{10}$ ressalta que há coisas que só podem ser expressas pela música. O discurso sobre a música é, por definição, não musical sendo, portanto, uma espécie de tradução, em outro registro, daquilo que a música pode ou deve dizer.

Adotamos essa perspectiva acreditando que, mesmo em uma linguagem acadêmica, seja possível a construção de uma poética do falar sobre a música, com uso de metáforas, analogias, mas conscientes de que essa tradução propõe sempre uma aproximação com o sentido original (não atingindo jamais uma transposição literal). Compreender essa especificidade significa também admitir que o sistema musical não deve nem pode ser confundido com outros ou equiparado a outros em suas funções. Partindo da premissa da especificidade da experiência estética musical, Blacking ${ }^{10}$ afirma: "Estou preocupado com as funções cognitivas da música e, na seção final deste trabalho, sugiro que o fazer musical 'pode ser' uma ferramenta indispensável para a intensificação e a transformação da 'consciência' como um primeiro passo para transformar as formas sociais. ${ }^{10}$ (p. 208). Entender a música como sistema modelar 'primário' significa dizer que a ação social musical 'pode moldar' outros tipos de ação social, invertendo a clássica superposição infraestrutura, superestrutura.

Falar sobre a música seria sempre, portanto, uma aproximação imprecisa, que jamais refletiria de forma transparente aquilo que a música é capaz de representar. Da mesma forma que o testemunho, o discurso sobre a música também padece de uma incompletude, por jamais poder traduzir de maneira fiel aquilo que a música em si representa.

Em decorrência dessas premissas, entendemos que seria impossível para qualquer linguagem traduzir de forma naturalística, buscando precisão e objetividade na construção de 'uma verdade', tanto a realidade das experiências motivadoras do trauma, no testemunho, quanto o que a música diz.

No entanto, de forma semelhante ao que foi concebido em relação ao testemunho, como propôs Seligmann-Silva ${ }^{8}$, a análise discursiva pode possibilitar uma compreensão da música vinculando seu contexto de produção à sua forma, aos elementos da musicalidade e às palavras escolhidas para compor sua letra.

Assim, podemos entender que a música, ou mais especificamente a canção popular, pode, além de outras funções, desempenhar o papel de testemunho, produzindo uma forma particular de expressão sobre uma experiência na memória coletiva. Neste caso, a necessidade expressiva do testemunho pode ter a forma sublimatória de canção ou poema, como nos diz Agamben": "Não é o poema ou o canto que podem intervir para salvar o impossível do testemunho; pelo contrário, se muito, é o testemunho que pode fundar a possibilidade do poema” (p. 45).

Semprún ${ }^{16}$, em seu testemunho da experiência vivida no campo de concentração em Buchenwald, afirma: "No entanto, vem-me uma dúvida sobre a possibilidade de contar. Não que a experiência vivida seja indizível. Ela foi invivível, o que é outra coisa, como se compreenderá facilmente. Outra coisa que não se refere à forma de um relato possível, mas à sua substância. Não à sua articulação, mas à sua densidade. Só alcançarão essa substância, essa densidade transparente, os que souberem fazer de seu testemunho um objeto artístico, um espaço de criação. Ou de recriação. Só o artifício de um relato que se possa controlar conseguirá transmitir parcialmente a verdade do testemunho. Mas isso não tem nada de excepcional: é o que acontece com todas as grandes experiências históricas" ${ }^{{ }^{16}}$ (p. 13).

Depois de um breve preâmbulo otimista sobre as infinitas possibilidades de expressão que a linguagem oferece - "pode-se dizer tudo" (p. 14), Semprún ${ }^{16}$ questiona - na esperança de que, um dia, com coragem, habilidade e determinação, seja possível traduzir em testemunho pelo menos parte do horror vivido - se alguém dará ouvidos ao testemunho. Se for possível dizer tudo, o que pensar, em contrapartida, sobre a escuta? "Mas pode-se tudo ouvir, tudo imaginar? Poder-se-á ouvir, imaginar? Terão eles a paciência, a compaixão, o rigor necessários?"16 (p. 14).

Paciência, compaixão, compartilhamento de afetos, escuta, acolhimento, empatia se apresentam como formas de nomear a disponibilidade para o restabelecimento de laços sociais rompidos de forma traumática. 


\section{ANGÉLICA E PEDAÇO DE MIM: INSCRIÇÕES DO TRAUMA E DA PERDA NA MEMÓRIA COLETIVA}

Considerando a expressão musical como uma forma de testemunho específica e irredutível, podemos nos apoiar nas análises de Seligmann-Silva ${ }^{8}$ sobre sua capacidade expressiva de simbolizar experiências traumáticas e transformar o social através do papel ativo do artista. O autor afirma que, na Música Popular Brasileira, podemos encontrar inúmeros exemplos de inscrições do trauma, como "escritura de uma contravoz"8 (p. 114), entre as quais a canção Angélica, de Chico Buarque. Chama de contravoz a luta do músico por registrar sua expressão sobre eventos do passado na memória coletiva (como no caso da ditadura civil militar) em que "o conservadorismo gigantesco da sociedade brasileira tende mais para enterrar aquele passado ainda recente do que para lembrar"8 (p. 114). Compreende ainda que a anistia concedida a artistas e políticos em 1979 teria contribuído para promover um esquecimento sobre as arbitrariedades e violências cometidas.

Chico Buarque, compositor consagrado como um dos grandes nomes da canção brasileira, foi tema do livro Quem é essa mulher? ${ }^{15}$, sobre as representações do feminino em sua obra musical. Em matéria sobre o livro, o autor, Alberto Lima, afirma em seu depoimento serem duas as canções em que Chico alude à tragédia pessoal de Zuzu Angel: “ 'Quem escreveu o prefácio [...] foi a jornalista Hildegard Angel, filha da grande estilista brasileira Zuzu Angel e irmã de Stuart, ambos mortos no regime militar pelo governo'. Apesar de Alberto não a conhecer pessoalmente, desde o início pensou na jornalista por conta da história de sua família e ela aceitou rapidamente. 'Zuzu foi homenageada por Chico nas canções Angélica e Pedaço de mim, além de ser uma forte mulher atuante na luta contra a ditadura', relata o autor" ${ }^{\text {”17. }}$

O próprio Chico, em entrevista concedida à rádio nos anos 1980, falou sobre sua relação pessoal com a estilista Zuzu Angel ${ }^{18}$ : "Eu conheci muito a Zuzu. Ela foi uma mulher que durante anos depois da morte do filho (Stuart Angel Jones, preso político em 1971) não fez outra coisa senão se dedicar a denunciar os assassinos do filho, a reivindicar o direito de saber aonde é que estava o corpo dele. Ela ia de porta em porta mesmo. E lá em casa ela ia com muita frequência, como em outras casas também. Ela sabia, inclusive, das ameaças que pairavam sobre ela e dizia que tinha certeza que se alguma coisa acontecesse com ela a culpa seria dos mesmos assassinos do filho, que ela citava nominalmente. Na manhã do dia em que aconteceu o acidente com ela, ela tinha estado lá em casa e deixado as camisetas que ela fazia, gravadas com aqueles anjinhos que eram a marca dela, para as minhas três filhas. Aquilo me chocou muito. Ela passava em casa quase semanalmente, mostrando os relatórios todos do trabalho que ela estava fazendo aqui e nos Estados Unidos - porque afinal, o pai do Stuart era americano -, então ela tinha contato com senadores americanos, inclusive alguns dos quais me lembro até hoje, como o Frank Church, o Mondale, que era um dos senadores com quem ela contava - nunca contou com o Reagan evidentemente... Ela tinha, inclusive, na lista dela, uma relação das posições políticas dos senadores e tinha até alguns 'ultraconservatives' (ultraconservadores) que, por se tratar de um filho de cidadão americano, eram simpáticos ao clamor de mãe dessa mulher. Ela chegou a entregar a documentação ao Kissinger pessoalmente, se não me engano, no Hotel Sheraton, quando ele esteve aqui. Clandestinamente ela furou o bloqueio e, um pouco depois, lhe entregou uma pasta com os documentos todos que ela tinha e distribuía entre as pessoas em quem confiava, gostava. Ela morreu um pouco depois disso"18.

O artista testemunhou de diversas formas a história de Zuzu e o período da ditadura civil militar. Como falamos anteriormente, ele é o testis neste caso. Chico compôs canções sobre a dor da história particular e sobre a dor daquele período histórico, que ele também viveu. O músico e a estilista faziam parte do mesmo grupo de pertencimento, nomeado neste trabalho de classe média intelectualizada. Chico Buarque foi submetido, desde 1966, à censura de várias de suas produções, tendo sido detido em sua própria casa, após a decretação do Ato Institucional no 5, em 1968, e decidido se exilar no ano seguinte. Em seu retorno do exílio, foi um dos artistas a receber uma das cartas-denúncia de $\mathrm{Zuzu}^{2,17}$. É, portanto, testemunha não imparcial. 
A canção Angélica composta em parceria com o músico Miltinho, embora gravada apenas em 1981 no long-play Almanaque, data do ano de $1977^{19}$. O arranjo ficou por responsabilidade de Dori Caymmi. Além do piano de Francis Hime, a faixa conta ainda com acompanhamento de violão, baixo elétrico e naipe de cordas.

Apresentamos abaixo a letra da música e acrescentamos, na análise, características relacionadas à sua melodia.

"Quem é essa mulher/que canta sempre esse estribilho? Só queria embalar meu filho/que mora na escuridão do mar. Quem é essa mulher/que canta sempre esse lamento? Só queria lembrar o tormento/que fez meu filho suspirar. Quem é essa mulher/que canta sempre o mesmo arranjo? Só queria agasalhar meu anjo/e deixar seu corpo descansar. Quem é essa mulher/que canta como dobra um sino? Queria cantar por meu menino/que ele não pode mais cantar"19.

Ressaltamos na letra, assim como Seligmann-Silva ${ }^{8}$, a cena da mãe que quer enterrar seu filho para que possa vivenciar a perda em forma de luto, cicatrizar a ferida exposta. Não ter o corpo para enterrar é perpetuar a dor, revivê-la, repeti-la. Na letra está presente a dualidade do trauma entre lembrar e esquecer, cantar e calar.

O eu lírico é um recurso interessante usado pelo músico, quando oscila entre primeira e terceira pessoas: 'Quem é essa mulher?' ${ }^{19} \mathrm{e}$ 'Só queria embalar MEU filho' ${ }^{19}$. O músico transita entre 'incorporar' o lugar de alguém que desconhece a história e o da mãe que pede, lamenta, canta. $\mathrm{O}$ eu lírico ajuda o músico a assumir o lugar de fala do protagonista (através do eu lírico é possível narrar sobre um tema não vivido diretamente pelo indivíduo) e a chamar atenção para o lugar do ouvinte (personagem ou quem ouve a canção). A cantilena de Zuzu, no entanto, é comparada a um sino, cujo som pode ser irritante, desagradável. Chamar a atenção do outro pode ter como resultado a solidariedade, como quando Zuzu conseguiu chamar atenção do ouvinte/ músico, mas é um risco, podendo comprometer a segurança de quem insiste em testemunhar. Enfatizamos, desse modo, o objetivo de transformação social de que fala Seligmann-Silva ${ }^{8}$.

Destacamos também uma forte conexão entre música e letra. A canção não possui refrão. As estrofes possuem estrutura assimétrica - não há uniformidade na métrica dos versos no interior de cada uma delas -, porém se repetem ao longo da canção, como se quisessem expressar, por analogia, a repetitividade do relato do trauma, a repetição dos pedidos de Zuzu pelo corpo de seu filho. Por sua vez, a assimetria nos deixa a impressão de que falta algo para completar um suposto equilíbrio ideal dos versos no interior da estrofe. A exemplo da estrutura dos versos, cada estrofe repete a mesma melodia. A voz de Chico Buarque é acompanhada por piano, violão e baixo, nas duas primeiras estrofes. Na terceira, um naipe de cordas dá maior consistência ao arranjo e serve como preparação para a estrofe final - na verdade, uma repetição da estrofe inicial -, quando há uma modulação e a mesma melodia/letra é executada alguns tons acima, produzindo um efeito de intensificação do lamento.

Assimetria, repetição e intensificação são recursos estéticos que apoiam a construção de uma ambiência sensorial propícia à representação do trauma, que almeja atingir a sensibilidade e conquistar a empatia de um outro que escuta. São caminhos próprios que a canção trilha para criar a ambiência da história da estilista e da dor do luto não realizado.

A voz de Zuzu Angel foi interrompida precocemente, assim como a de seu filho. Ambos são anjos para o músico-compositor. As mortes precoces são um inexplicado que ainda parece mobilizá-lo em Pedaço de mim, também composta em 1977, mas gravada em 1978, no long-play Chico Buarque em dueto com a cantora Zizi Possi²0.

"Oh, pedaço de mim/Oh, metade afastada de mim/Leva o teu olhar/Que a saudade é o pior tormento/É pior do que o esquecimento/ É pior do que se entrevar. Oh, pedaço de mim/Oh, metade exilada de mim/Leva os teus sinais/Que a saudade dói como um barco/Que aos poucos descreve um arco/E evita atracar no cais. Oh, pedaço de mim/Oh, metade arrancada de mim/Leva o vulto teu/Que a saudade é o revés de um parto/A saudade é arrumar o quarto/Do filho que 
já morreu. Oh, pedaço de mim/Oh, metade amputada de mim/Leva o que há de ti/Que a saudade dói latejada/É assim como uma fisgada/No membro que já perdi. Oh, pedaço de mim/Oh, metade adorada de mim/Lava os olhos meus/Que a saudade é o pior castigo/E eu não quero levar comigo/A mortalha do amor/Adeus”20.

A versão original conta com a participação de Milton Nascimento no piano, que já no início faz um preâmbulo instrumental à canção. A primeira estrofe é cantada por Zizi Possi, acompanhada do violão de Nelson Angelo. A segunda é cantada por Chico Buarque, com acompanhamento de violão e piano. Aqui, no momento em que pronuncia a palavra "cais" ${ }^{20}$, irrompe o bandolim de Beto Guedes num toque melancólico, típico dos fados portugueses. O solo do bandolim acompanha toda a interpretação de Zizi Possi, ao longo da terceira estrofe, junto com acordes de piano e violão. Quando a intérprete pronuncia "Leva o vulto teu”"20, entra o peso do baixo elétrico de Novelli, responsável por dar um ar de gravidade ao verso "A saudade é arrumar o quarto/Do filho que já morreu”º, que encerra essa estrofe. Na estrofe seguinte, Chico Buarque canta acompanhado de todos esses instrumentos, enquanto a voz de Zizi Possi, como se fosse mais um instrumento, vocaliza outra melodia, tal qual um canto de sereia ecoando ao longe. Em seguida, os dois cantam juntos a última estrofe acompanhados de todos os instrumentos. Ao longo da canção, o arranjo vai incorporando um novo instrumento a cada estrofe, fazendo com que, aos poucos, a sonoridade se torne mais encorpada e o lamento mais intenso. Crescendo gradativamente, a canção prepara o ouvinte para o clímax que acontece na última estrofe. Ali, já com todos os instrumentos, os cantores entrelaçam suas vozes harmonicamente numa dramática interpretação antes do acorde final.

A estrutura é análoga à da canção Angélica, com assimetria dos versos e repetição das estrofes sem refrão. A melodia também se repete a cada estrofe. A dualidade lembrar/esquecer é materializada nas dualidades parte/todo, realidade/memória, corpo/espírito ou experiência vivida/experiência compartilhada, como em Benjamin7, nas palavras da canção "pedaço", "metade amputada", "sinais" e "vulto". O tema da mãe que perde o filho se repete na estrofe em que opõe o parto (nascimento) e a morte (tendo a palavra "parto" também o sentido de presente do indicativo do verbo partir). A dor causada por esse tipo de perda é comparada às piores dores físicas ("pior do que se entrevar"), ou imaginárias (“como uma fisgada/No membro que já perdi”), tendo a palavra "membro" os sentidos de parte do corpo e parte da família). A saudade é a dor viva que traz de volta o vulto de um ser que já não vive.

O eu lírico não oscila nessa canção: o músico ocupa definitivamente o lugar de fala de quem sofreu a perda.

\section{CONSIDERAÇÕES FINAIS}

Vivemos uma época em que a contestação das instâncias de verdade alcança proporções talvez nunca antes imaginadas. Se por um lado, na modernidade, como vaticinou Benjamin7 , à valorização da experiência individual se contrapõe a pulverização da capacidade de narrar essa experiência, tornando-a incomunicável; por outro lado também é lícito resgatar Halbwachs", quando ele aponta sob que condições ainda seria possível uma eventual identificação empática com o testemunho alheio. Uma dessas condições consiste na capacidade de nos colocarmos temporariamente no ponto de vista da testemunha. É essa disposição mútua, quando compartilhada entre os integrantes de uma mesma coletividade, que permite a incorporação de um testemunho individual à memória coletiva de um grupo.

Já Agamben ${ }^{6}$ aponta que única verdade incontestável de qualquer testemunho é precisamente sua insuficiência de dar conta, em sua totalidade, da experiência relatada, pois a realidade sempre será mais complexa e multifacetada do que a capacidade de narrá-la. O testemunho verdadeiro, portanto, seria aquele que admite com a maior honestidade possível essa incapacidade. Semprún ${ }^{16}$, em suas memórias do campo de concentração, e Seligmann-Silva ${ }^{8}$ ao abordarem diversos exemplos de testemunhos, a partir de eventos que conceituam como "catástrofes históricas", reiteram a tese da insuficiência do testemunho. Afirmam a necessidade de explorar as possibilidades e os limites da linguagem na busca por uma forma de traduzir, 
ao menos em parte, o horror do trauma. Nesse ponto, a construção do testemunho pode ser comparada ao processo criativo do artista. A partir daí, Blacking ${ }^{10}$ aporta elementos que nos permitem atribuir à música propriedades singulares, capazes de expressar domínios específicos da experiência humana. Sugerimos que aspectos da memória vinculados à experiência sensível e afetiva têm na música uma forma privilegiada de expressão e compartilhamento. Por isso a relevância de tratarmos da canção como testemunho e do lugar do artista na construção da memória coletiva.

Nas duas canções de Chico Buarque, identificamos características peculiares à canção como testemunho. Entre elas, a capacidade de, como eu lírico, o músico colocar-se imaginariamente no lugar de uma mãe que perdeu o filho e, a partir desse deslocamento, traduzir simbolicamente a experiência íntima da dor em algo passível de ser compartilhado por outros que, como ele, não vivenciaram diretamente aquela experiência. No entanto, o artista testemunhou a experiência. Sua tentativa de mobilizar empatia se aproxima do objetivo de transformação social que o testemunho do trauma buscaria, de acordo com Seligmann-Silva ${ }^{8}$.

Entendemos, em afinidade com Halbwachs ${ }^{9}$ e Semprún ${ }^{16}$, que a faculdade do artista em se projetar nesse lugar da experiência vivida por outrem é fundamental para produzir um testemunho passível de empatia e, portanto, apto a ser incorporado à memória coletiva. Contudo, apenas esse deslocamento não é o suficiente. É necessário, além dessa sensibilidade, a disposição e a perícia necessárias para explorar as possibilidades das linguagens musical e poética de modo a fazer do testemunho do trauma uma expressão absolutamente não convencional em sua forma, dado que a experiência que relata também foge do convencional.

Se, como afirma Agamben ${ }^{6}$, "O sobrevivente tem a vocação da memória. Não pode deixar de recordar" (p. 36), o testemunho é, nesse caso, um imperativo que funda a própria possibilidade de existência dessas canções e dá a elas a sua potência.

As canções de Chico são representações habilmente estetizadas de uma dor que ele não viveu, mas que, contudo, pôde imaginar sentir, e que nos instigam a revivê-la como memória coletiva. Parafraseando Fernando Pessoa, não é precisamente a capacidade de sentirmos (deveras) a dor que fingimos sentir que faz da empatia uma virtude essencial à poesia?

\section{REFERÊNCIAS}

1. Bolsonaro nega ditadura e diz que regime viveu probleminhas. Folha de S.Paulo [Internet]. 2019 mar. 27 [citado em 2020 out. 14];Poder. Disponível em: https://www1.folha.uol.com.br/poder/2019/03/naohouve-ditadura-teve-uns-probleminhas-diz-bolsonaro-sobre-regime-militar-no-pais.shtml.

2. Bernstein M, Rezende S. Zuzu Angel. São Paulo: Imprensa Oficial; 2006.

3. Instituto Zuzu Angel [Internet]. Rio de Janeiro: O Instituto; 1993 [citado em 2019 jul. 10]. Disponível em: https://www.zuzuangel.com.br.

4. Otavio C, Piva JD. Stuart Angel: verdadeiro nome do principal torturador é descoberto. O Globo [Internet]. 2013 set. 22 [citado em 2020 out. 14]. Disponível em: https://oglobo.globo.com/brasil/ stuart-angel-verdadeiro-nome-doprincipal-torturador-descoberto-10084684.

5. Talento A. Ex-delegado do Dops diz que morte de Zuzu Angel foi planejada pela ditadura. Folha de S.Paulo [Internet]. 2014 jul. 23 [citado em 2020 out. 14];Poder. Disponível em: https://www1.folha.uol. com.br/poder/2014/07/1490254-ex-delegado-do-dops-diz-que-morte-de-zuzu-angel-foi-planejada-peladitadura.shtml.

6. Agamben G. O que resta de Auschwitz: o arquivo e a testemunha. São Paulo: Boitempo; 2008.

7. Benjamin W. Obras escolhidas: magia, técnica, arte e política. 7. ed. São Paulo: Brasiliense; 1994.

8. Seligmann-Silva M. Narrar o trauma: escrituras híbridas das catástrofes. Rev. Gragoatá. 2008:(24):101-17.

9. Halbwachs M. A memória coletiva. São Paulo: Vértice; 1990.

10. Blacking J. Música, cultura e experiência. Cad Campo. 2007 dez;16(16):201-18. 
11. Almeida MHT, Weis L. Carro-zero e pau de arara: o cotidiano de oposição da classe média ao regime militar. In: Novais FA, Schwarcz LM. História da vida privada no Brasil: contrastes da intimidade contemporânea. São Paulo: Companhia das Letras; 2007. p. 319-409.

12. Birman J. Escrita, trauma e violência em psicanálise. Cad Psicanálise. 2014;30(33):19-47.

13. Williams R. Cultura. Rio de Janeiro: Paz e Terra; 1992.

14. Gomes IMM. Raymond Williams e a hipótese cultural da estrutura de sentimento. In: Gomes IMM, Janotti Júnior JS. Comunicação e estudos culturais. Salvador: EDUFBA; 2011. p. 29-49.

15. Lima A. Quem é essa mulher? Recife: CEPE Editora; 2017.

16. Semprún J. A escrita ou a vida. São Paulo: Letras Cd; 1995.

17. Vieira L. Livro analisa músicas de Chico Buarque que falam sobre mulher. Correio Braziliense [Internet]. 2017 dez. 08 [citado em 2020 out. 14];Diversão e Arte. Disponível em: https://bit.ly/2IvGE5U.

18. Buarque C. Notas sobre Angélica [Internet]. Entrevista concedida à Rádio Atividade. Centro Cultural São Paulo, 1985 [citado em 2019 jul. 10]. Disponível em: http://www.chicobuarque.com.br/letras/notas/n angelica.htm.

19. Buarque C. Angélica [Internet]. [citado em 2019 jul. 10]. Disponível em: http://www.chicobuarque.com. br/construcao/mestre.asp?pg=angelica $77 . \mathrm{htm}$.

20. Buarque C. Pedaço de mim [Internet]. [citado em 2019 jul. 10]. Disponível em: http://www. chicobuarque.com.br/construcao/mestre.asp?pg=pedacode $77 . \mathrm{htm}$. 